\title{
Economic analysis of cucumber and lettuce intercropping under greenhouse in the winter-spring
}

\author{
BRÁUlIO L.A. REZENDE ${ }^{1}$, ARTHUR B. CECílIO FILHO ${ }^{2}$, AURÉLIO P. BARROS JÚNIOR ${ }^{2}$, \\ DIEGO R.Q. PORTO ${ }^{2}$ and MARIA INEZ E.G. MARTINS ${ }^{3}$ \\ ${ }^{1}$ Universidade Estadual de Ponta Grossa, UEPG, Departamento de Fitotecnia e Fitossanidade \\ Av. Carlos Cavalcanti, 4748, 84030-900 Ponta Grossa, PR, Brasil \\ ${ }^{2}$ Universidade Estadual de São Paulo, UNESP, Departamento de Produção Vegetal \\ Via de acesso Prof. Paulo D. Castellane, s/n, 14884-900 Jaboticabal, SP, Brasil \\ ${ }^{3}$ Universidade Estadual de São Paulo, UNESP, Departamento de Economia \\ Via de Acesso Prof. Paulo D. Castellane, s/n, 14884-900 Jaboticabal, SP, Brasil \\ Manuscript received on August 24, 2009; accepted for publication on October 25, 2010
}

\begin{abstract}
The economical analysis complements the evaluation of the intercrop systems efficiency, considering besides the physical production of crops, the price of products according to their quality classification and time of the year. Intercropping systems of lettuce and cucumber in two plant populations under greenhouse were economically evaluated in winter-spring, in Jaboticabal City, São Paulo State, Brazil. The total operating cost (TOC) of cucumber and lettuce as sole crop and intercropping were estimated, as well as gross revenue (GR) and operating profit (OP). The labor for the crops was the component with greater participation in the TOC of crops in intercropping and single crop. Greater GR and OP were observed in intercrops established by transplanting lettuce and cucumbers on the same day. Considering the operating profit and the land efficient ratio, it is recommended the intercropping of lettuce transplanted until 10 days after the transplanting (DAT) of cucumber with two rows per plot, and at 0 DAT of cucumber grown with a row plot.
\end{abstract}

Key words: Lactuca sativa, Cucumis sativus, economics, agronomic efficiency.

\section{INTRODUCTION}

Cucumber and lettuce are vegetables of great importance in the olericulture worldwide. In the conditions of the south-east region of Brazil, these vegetables require protected cultivation, so that products of optimum market quality can be obtained, especially at the end of spring, in summer and at the beginning of fall when rain is intense, or in winter when temperatures are low.

A technology that can be added to that of protected cultivation is the intercropping of vegetables, in which two or more vegetables are grown simultaneously on the same area, or at least during part of their cycles. Be-

Correspondence to: Arthur Bernardes Cecílio Filho

E-mail: rutra@fcav.unesp.br sides the direct advantages, such as the increase in food production on the same area used for sole crop, and the indirect advantages, such as greater biological diversity, better use of the area by the grower and the consequent reduction in environmental impact, intercropping can give a profitability either through a better use of the available labor fertilizers and chemicals applied, or machinery-hours and energy spent in the production process (Cecílio Filho 2005).

Nonetheless, to adequately analyze the efficiency of intercropping, Rezende et al. (2005b) point out that, besides the ratio to quantify the yielding advantage of intercropping over sole crop, and for greater security in the recommendation of this technology, an economic analysis must be carried out since vegetables vary in 
yield, price and production cost year-round. Moreover, intercropping may have a negative effect on the market quality (color, size, shape, etc) of the product, lowering its grade designation and consequently reducing its commercial value.

Economic analysis permits to identify the strengths and weaknesses of technical and economic results, to take immediate and decisive action, at any time, and to solve problems affecting the agricultural activity, helping the grower to manage and use the available resources more efficiently, favoring their maximization and increasing the level of the production system with a simultaneous reduction in costs (Santos and Junqueira 2004). Thus, an economic analysis of cucumber and lettuce intercropping in a protected environment was carried out with the aim of increasing the grower's profitability.

\section{MATERIALS AND METHODS}

The yields of cucumber and lettuce crops as well as the land equivalent ratios were obtained from two experiments in two populations of plants conducted in greenhouses, from August to November 2005, in Jaboticabal City, located at $21^{\circ} 15^{\prime} 22^{\prime \prime} \mathrm{S}, 48^{\circ} 15^{\prime} 58^{\prime \prime} \mathrm{W}$ and at $575 \mathrm{~m}$ height, in São Paulo State, Brazil.

Nine treatments from combinations of two factors were evaluated in each experiment. The factors consisted of cultivation system (intercropping and sole crop) and transplanting date of lettuce $(0,10,20$ and 30 days after the transplanting of cucumber). The experimental design, for each experiment, was a randomized complete blocks, with the treatments arranged in a factorial scheme $2 \times 4+1$ with four replications. The treatments 1, 2, 3 and 4 corresponded to the intercropping system with lettuce transplanted at $0,10,20$ and 30 days after the transplanting (DAT) of cucumber. The treatments 5 , 6,7 and 8 represented the sole crop system of lettuce at the same time the intercroppings were established in order to isolate a possible effect of the planting time factor. Treatment 9 corresponded to the sole crop of cucumber (additional treatment). The total area of each plot was $1.10 \times 2.50 \mathrm{~m}\left(2.75 \mathrm{~m}^{2}\right)$ containing 40 plants of lettuce, ten and five plants of cucumber for treatments with two and one row of cucumber, respectively. The boundary of the plot corresponded to the first and last plants of each crop row.
The two experiments differed from each other in their cucumber plant populations. One experiment consisted of two rows of cucumber that were cultivated, whereas in the other experiment, one row of cucumber had was cultivated in the center of the lettuce bed (Fig. 1). Planting distances were $0.60 \times 0.50 \mathrm{~m}$, with $0.50 \mathrm{~m}$ between plants in the row, for cucumber cultivated in one or two rows on the bed, and $0.25 \times 0.25 \mathrm{~m}$ for lettuce.

Preparation of the soil consisted in applying a herbicide (a $20 \mathrm{~L}$ backpack sprayer) for the removal of weeds, and plowing, for which a "three-26" disk plow was used.

Organic fertilization of the soil at planting time required labor for the spreading of cattle manure applied in $614.4 \mathrm{~m}^{2}$, and a rotary hoe to incorporate it into the soil. For chemical fertilization, the labor for the spreading of fertilizers was considered separately for each crop, as recommended by Trani et al. (1997a, b). For intercropping, fertilization at planting time was based on the crop with higher nutrient requirements (cucumber). Results of the soil chemical analysis indicated that liming was not needed. The amount of fertilizer applied at planting time was $2 \mathrm{~kg} \mathrm{~m}^{-2}$ of cattle manure and $35 \mathrm{~g} \mathrm{~m}^{-2}$ of the formulation 12-06-12. For cucumber, potassium chloride and ammonium nitrate were applied four times, at 15, 25, 35 and 45 DAT. In each date, the amounts applied of ammonium nitrate were $5 \mathrm{~g} \mathrm{plant}^{-1}$, whereas the amount of potassium chloride furnished was $2 \mathrm{~g} \mathrm{plant}^{-1}$, in the first and second applications, and $2.5 \mathrm{~g}$ plant $^{-1}$ in the third and fourth sidedressing. Sidedressing of lettuce was carried out at 15 and 30 DAT, when $2 \mathrm{~g} \mathrm{plant}^{-1}$ of ammonium nitrate were furnished.

A $1.10 \mathrm{~m}$ wide rotary hoe was used for the preparation of six $48 \mathrm{~m}$ long beds, followed by the holes manually made where the transplant of lettuce 'Verônica' and cucumber 'Hokushin', of the Japanese type, were laid. The cultivars of lettuce and cucumber that were chosen are the most widely cultivated in southeastern Brazil.

The seedlings of cucumber were grown in 128-cell trays, and were transplanted on one single date when they had one true leaf besides the cotyledonary leaves. The seedlings of lettuce were grown in 288-cell trays and when the plants had four true leaves, they were transplanted at 10-day intervals, up to 30 DAT of cucumber, according to treatments. 


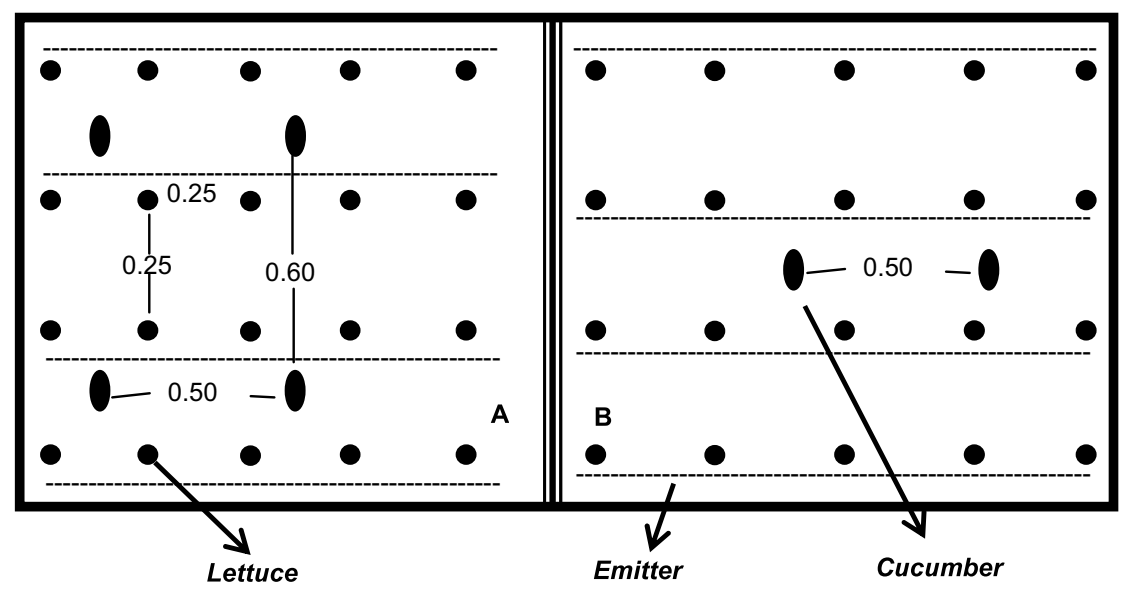

Fig. 1 - Graph of the plots with lettuce and cucumber in two plant population intercropping systems: A - lettuce $(0.25 \times 0.25 \mathrm{~m})$ and cucumber with two rows on the bed $(0.60 \times 0.50 \mathrm{~m})$ and $\mathrm{B}$ - lettuce and cucumber with one row on the bed $(0.50 \mathrm{~m}$ between plants in the row $)$.

The cucumber was trained up using posts spaced $12 \mathrm{~m}$ apart, braces and six wires number 12 (one near the soil surface and the others at every $0.40 \mathrm{~m}$ to the height of $2 \mathrm{~m}$ ). The cucumber plants were trained on a single stem, with a plastic twine tied between the wires to support the plants. Lateral runners up to the height of $0.40 \mathrm{~m}$ were suckered, and above this point the shoots were left for the setting of two fruits, with the branch topped after the third leaf, fastened to the wires $40 \mathrm{~cm}$ apart. The main stem was topped when the plant was nearly $2 \mathrm{~m}$ tall, about 19 nodes.

Drip irrigation was the system used to distribute water, with emitters placed $10 \mathrm{~cm}$ apart. The system consisted of a mainline and two sub-mains of emitters. For cucumber cultivated in sole crop, with one and two rows on the bed, one and two tapes of emitters were used, respectively, whereas for the lettuce and intercropping systems four tapes were used, that is, one tape per planting row. Since the emitter lines of this irrigation system were not moved from place to place in the greenhouse $\left(614.4 \mathrm{~m}^{2}\right)$, hand labor was based on the time needed to turn the water on and off, and on some repairs. Plants were irrigated daily for 30 minutes, on the average, throughout the growth stage of the crop, both in sole crop and intercropping.

The soil within and between the beds was hand hoed. For cucumber in sole crop, it was hoed two and three times throughout the growth stage, for the culti- vation with two and one row on the bed, respectively. For lettuce, in sole crop and intercropping, the soil was hoed twice.

Fungicides and insecticides were sprayed three times (backpack sprayer) on lettuce and 24 times on cucumber throughout their growth stage, in sole crop and intercropping.

Cucumber was harvested weekly at 36 up to 83 DAT. Lettuce was harvested on 6, 16 and 26/10 and 05/11, for treatments carried out at $0,10,20$ and 30 DAT of cucumber, respectively, totaling a 40 DAT growth stage. Washing, grading and storage of cucumber fruits and lettuces for marketing were considered postharvesting activities.

\section{DETERMINING THE TOTAL COST OF OPERATIONS}

The model used for the determination of the total operating cost (TOC) was the operating cost of production proposed by Matsunaga et al. (1976).

The price of every production item quoted in August 2006, the month in when the experiments started, was changed into real price using the General Price Index-Internal Supply (IGP-IS), August 2007 (R\$) value. Values in Reais were converted into U.S. dollars using the monthly average rate of exchange for August 2007 (US\$ 1.96).

All the technical coefficients relating to the operations, establishment and cultural practices used in 
the analysis of their production cost, were obtained throughout the period of time when the experiments were carried out.

Labor wages, obtained at the Rural Workers' Organization in Jaboticabal, were US\$ 205.99 for hand labor and US\$236.89 for tractor operator, for 200 hours worked per month, besides social security contributions payable by the employer, which represented $43 \%$ of the salary. Thus, hourly costs were US\$ 1.48 and US\$ 1.69 for hand labor and tractor operator, respectively.

Nominal prices for materials were obtained in the region of Jaboticabal, whereas the prices of tractor MF275 and plow were obtained in the database of Instituto de Economia Agrícola (IEA).

To determine the hourly cost of the machinery (MHC), tractor MF 275 (77 hp), insurance premium (i), shelter $(s)$, plus estimated costs for repairs $(r)$, maintenance $(m)$ and cost of fuel $(f)$ were included as follows: $M H C=i+s+r+m+f$. Insurance, shelter and repairs represented $0.75 \%, 1 \%$ and $10 \%$ a year of the cost of the machine, respectively, considering 1,000 hours of use of the machine, besides maintenance cost. To calculate the maintenance cost of tractor $275(77 \mathrm{hp})$, the costs concerning lubricants (oils and grease) and replacement items of the machine (filters), following the replacement schedule recommended by the manufacturer, were included. Partial hourly cost of the tractor (excluding the cost of fuel) was US\$ 6.30.

For the hourly cost of implements (IHC), grease consumption and repairs were represented as follows: $I H C=r+g r$; where $r=$ repairs, corresponding to $10 \%$ of the value of the implement per year, and $g r=$ grease [grease cost $=$ consumption $\left(\mathrm{kg} \mathrm{h}^{-1}\right) \times$ price of grease per kilogram] (Table I).

Depreciation was calculated using the straight line method, in which the value of a machine is reduced to an equal amount during its useful life, as expressed in the following formula: $D=(I v-S v) / N . H$; where: $D=$ Depreciation in US\$/hour or day; $I v=$ Initial value (new); $S v=$ Salvage value; $N=$ useful life (years) and $H=$ hours of annual use. The salvage value considered for the tractor corresponded to $20 \%$ of the initial value, whereas for implements it corresponded to zero (Table I).

The sum of the hourly cost of the tractor, imple- ments and fuel spent on each operation went into the hourly cost of the operations (Table I).

\section{DETERMINING THE GROSS REVENUE AND OPERATING PROFIT}

The lettuce population, in both cropping systems (intercropping and sole crop), was 4,608 plants in four rows on the bed, whereas the cucumber populations were 1,152 and 576 plants for plots with rows and one row of plants on the bed, respectively. Both crops were transplanted into six beds, which were $48 \mathrm{~m}$ long and $1.10 \mathrm{~m}$ wide.

The lettuce was designated a class using the average mass of the lettuce, according to HORTIBRASIL (2006); class $10\left(100 \geq \mathrm{a}<150\right.$ g plant $\left.^{-1}\right)$; class 15 (150 $\geq \mathrm{a}<200$ g plant $\left.^{-1}\right) ;$ class $20\left(200 \geq \mathrm{a}<250\right.$ g plant $\left.^{-1}\right)$ and class $25\left(250 \geq \mathrm{a}<300 \mathrm{~g} \mathrm{plant}^{-1}\right)$. The grading adopted for cucumber, based on the length of the fruits, and according to HORTIBRASIL (2006), was: class 15 $(15 \geq \mathrm{a}<20 \mathrm{~cm})$, class $20(20 \geq \mathrm{a}<25 \mathrm{~cm})$ and class 25 ( $\geq 25 \mathrm{~cm})$.

Given the difficulty to know the price received by the grower of cucumber and lettuce in the region of Jaboticabal, SP, Brazil, the average monthly price of the wholesale sector (CEAGESP 2006) was used minus $30 \%$, which corresponds to the grower's expenditure on packing, freight, loading and unloading, special rural social security contribution (CESSR) and commissions (Table II). For cucumber, the price during the harvesting time, October to November, was averaged.

The gross revenue (GR) was obtained by multiplying the production (Table $\mathrm{V}$ ) by the value of the crop product price of vegetables (Table II), and in the intercropping the calculation was accomplished individually for each crop and later it was made the add of values. The operating profit (OP) is the difference between the GR and the TOC. LER was calculated according to the formula:

$$
L E R=\frac{Y_{1}^{c}}{Y_{1}^{m}}+\frac{Y_{2}^{c}}{Y_{2}^{m}}+\frac{Y_{n}^{c}}{Y_{n}^{m}} \quad \text { so } \quad \sum_{i=1}^{n} Y c, i / Y m, i
$$

where:

$Y c, i=$ is the yield of "i" crop in intercropping (i), $Y m, i=$ is the yield of " $\mathrm{i}$ " crop in sole crop $(m)$. 
TABLE I

Unit price of items used for calculation of the production cost of the cucumber and lettuce crops. Jaboticabal, SP, Brazil, 2007.

\begin{tabular}{|c|c|c|c|c|c|c|}
\hline \multirow{2}{*}{\multicolumn{2}{|c|}{ Item }} & New value & Useful life & Annual use & $\mathrm{HC}^{4}$ & Depreciation \\
\hline & & US\$ ${ }^{1}$ & yea & - & US\$ & $\mathrm{US} \mathrm{h}^{-1}$ or day $^{-1}$ \\
\hline \multicolumn{2}{|c|}{ Tractor $275(77 \mathrm{hp})$} & $47,310.37$ & 10 & $1,000 \mathrm{~h}^{2}$ & 6.30 & 3.78 \\
\hline \multicolumn{2}{|c|}{ Rotary hoe } & $3,691.74$ & 8 & $480 \mathrm{~h}$ & 1.05 & 0.96 \\
\hline \multicolumn{2}{|c|}{ Backpack Sprayer (20 L) } & 80.25 & 5 & $120 \mathrm{~h}$ & 0.07 & 0.13 \\
\hline \multicolumn{2}{|c|}{ Motor pump - 1hp } & 230.07 & 10 & $300 \mathrm{~h}$ & 0.08 & 0.08 \\
\hline \multicolumn{2}{|c|}{$3-26^{\prime \prime}$-disk plow } & $2,297.34$ & 7 & $480 \mathrm{~h}$ & 0.66 & 0.68 \\
\hline \multicolumn{2}{|c|}{ Hand cart } & 64.21 & 4 & $270 \mathrm{~h}$ & 0.07 & 0.06 \\
\hline \multicolumn{2}{|c|}{ Greenhouse $\left(614.4 \mathrm{~m}^{2}\right)$} & $5,365.84$ & 10 & 365 days & - & 1.47 \\
\hline \multicolumn{2}{|c|}{ Emitter line - cucumber 2 rows $(588 \mathrm{~m})$} & 221.32 & 2 & 304 days & - & 0.37 \\
\hline \multicolumn{2}{|c|}{ Emitter line - cucumber 1 row $(294 \mathrm{~m})$} & 110.66 & 2 & 304 days & - & 0.18 \\
\hline \multicolumn{2}{|c|}{ Emitter line - lettuce $(1,176 \mathrm{~m})$} & 442.64 & 2 & 304 days & - & 0.73 \\
\hline \multicolumn{2}{|c|}{ Posts - cucumber 1 row (24 units) } & 256.85 & 15 & 330 days & - & 0.05 \\
\hline \multicolumn{2}{|c|}{ Posts - cucumber 2 rows (48 units } & 513.69 & 15 & 330 days & - & 0.10 \\
\hline \multicolumn{2}{|c|}{ Braces - cucumber 2 rows (144 units) } & 165.53 & 8 & 330 days & - & 0.06 \\
\hline \multicolumn{2}{|c|}{ Braces - cucumber 1 row (72 units) } & 82.77 & 8 & 330 days & - & 0.03 \\
\hline \multicolumn{7}{|c|}{ Operations } \\
\hline & $\mathrm{M}+\mathrm{I}^{3}$ & \multicolumn{2}{|c|}{ Fuel Consumption } & \multicolumn{2}{|c|}{ Fuel price } & $\mathrm{HC}^{4} \mathrm{M}+\mathrm{I}$ \\
\hline & & \multicolumn{2}{|c|}{$\mathrm{Lh}^{-1}$} & \multicolumn{2}{|c|}{$\mathrm{US} \$ \mathrm{~L}^{-1}$} & US\$ \\
\hline Plowing & Tractor + Plow & \multicolumn{2}{|l|}{11} & \multicolumn{2}{|c|}{1.03} & 18.31 \\
\hline Bedding & Tractor + Rotary hoe & \multicolumn{2}{|l|}{11} & \multicolumn{2}{|l|}{1.03} & 18.70 \\
\hline
\end{tabular}

${ }^{1}$ Price changed into real price using GPI-IS, base: August $/ 2007=100$. Values in Reais were converted into U.S. dollars using the monthly average rate of exchange for August 2007 (US\$ 1.966); ${ }^{2} \mathrm{~h}=$ hour; ${ }^{3} \mathrm{M}+\mathrm{I}=$ machine and implement; ${ }^{4} \mathrm{HC}=\mathrm{hourly}$ cost excluding depreciation.

TABLE II

Real average monthly price, per kilogram, of lettuce and cucumber, converted into (US\$) values for August 2007 using the GPI-IS. Jaboticabal, SP, Brazil, 2007.

\begin{tabular}{c|c|c|c|c}
\hline \multirow{2}{*}{ Vegetables } & \multirow{2}{*}{ CCC $^{1}$} & \multirow{2}{*}{ CPHD $^{2}$} & \multicolumn{2}{|c}{ Prices $^{3}$} \\
\cline { 3 - 5 } & & & October & November \\
\hline \multirow{3}{*}{ Lettuce } & First & Class 10 & 0.19 & 0.18 \\
\cline { 2 - 5 } & Special & Classes 15 and 20 & 0.28 & 0.27 \\
\cline { 2 - 5 } & Extra & Class 25 & 0.39 & 0.38 \\
\hline \multirow{3}{*}{ Cucumber } & Extra & Misshapen & 0.20 & 0.18 \\
\cline { 2 - 5 } & Extra A & Class 25 & 0.31 & 0.27 \\
\cline { 2 - 5 } & Extra AA & Classes 15+20 & 0.43 & 0.37 \\
\hline
\end{tabular}

${ }^{1}$ Common grading by authorized wholesalers at CEAGESP; ${ }^{2}$ Grading standards by Brazilian Institute of Quality in Horticulture; ${ }^{3}$ Price paid to grower based on wholesale price (CEAGESP). Values in Reais were converted into U.S. dollars using the monthly average rate of exchange for August 2007 (US\$ 1.966). 


\section{RESULTS AND DISCUSSION}

TOTAL COST OF OPERATIONS OF THE INTERCROPPING AND SOLE CROPS

Tables III and VI show in detail the production costs under protected cultivation of Japanese cucumber 'Hokushin', cultivated in two and one row on the bed, and lettuce 'Verônica', in sole crop and intercropping.

The total operating cost (TOC) for the sole crop of cucumber with two and one row on the bed and lettuce amounted to US\$ 1,151.16; US\$ 737.05 and US\$ 360.62 in $614.4 \mathrm{~m}^{2}$, respectively (Table III).

Technical coefficients concerning to labor confirm that olericulture is an important job-generating activity. In the sole crop system, 75.2 (lettuce) to 408.33 hours (cucumber with two rows) of hand labor (HL) and tractor operator's labor (TrOL) were used. The conversion of labor in the sole crop system into man-days (md) resulted in 51.0; 29.7 and $9.4 \mathrm{md}$ for cucumber with two and one row on the bed and lettuce in $614.4 \mathrm{~m}^{2}$, respectively (Table III).

The group of items with the largest impact on the TOC was that regarding operations, which amounted to US\$ 645.30; US\$ 390.94 and US\$ 148.98 in $614.4 \mathrm{~m}^{2}$ for cucumber with two and one row on the bed and lettuce, respectively. Of the total cost of operations in the sole crop system, on the average, $90.9 \%$ for cucumber (two and one row) and $72.6 \%$ for lettuce were due to HL. Rezende et al. (2005a) and Cecílio Filho (2005) evaluated intercropping of lettuce with tomato, in a protected environment, and the authors observed that HL was the most significant item that contributed to the operating expenses, $75.8 \%$ and $82.3 \%$, respectively.

HL was not only the most important item that contributed to the operating cost, but also the most costly in the TOC, accounting for 52.1, 47.2 and $30.0 \%$, for cucumber with two and one row on the bed and lettuce, respectively.

Under protected growing, Cecílio Filho (2005) also reported that the HL used for the cultivation of lettuce was the component with the largest percentage in the TOC, 25.6\%. This can also be observed in field condition, where the percentage of HL in the TOC is $37.1 \%$ for lettuce (Costa 2006), 25\% (Rezende et al. 2005a) and $32.1 \%$ (Costa 2006) for crisphead lettuce.
For cucumber under protected cultivation $\left(350 \mathrm{~m}^{2}\right)$, Cañizares (1998) found that the percentage of HL in the operating cost was $60.4 \%$, close to that found for cucumber cultivated in two rows on the bed (52.1\%). For cucumber in the sole crop system, regardless of the plant population, it was observed that more labor was required for harvesting and postharvesting operations, followed by training / suckering / cropping and application of chemicals (Table III). Cañizares (1998) also observed a higher HL requirement for harvesting and postharvesting operations (cleaning, sorting and packing), $49.7 \%$, similar to that observed for cucumber cultivated in two and one row on the bed (48.2\%).

A $42.0 \%$ reduction in the HL was verified for cucumber cultivated in one row on the bed, in comparison to the crop with a higher population density (Table III). A 50\% reduction in the number of plants resulted in a significant decrease in HL for plant training, application of chemicals, harvesting and postharvesting. Similarly to HL, a major reduction was observed in the total number of hours when the machines and implements $(\mathrm{M}+\mathrm{I})$ were used; in $614.4 \mathrm{~m}^{2}$, the reduction was of 118.85 and 80.92 hours for cucumber cultivated in two rows and one row on the bed, respectively.

The fruits of cucumber cultivated in one row on the bed were more exposed to solar radiation and more visible, thus facilitating pest control, training, suckering, and their harvesting.

Similarly to what was observed in cucumber, a higher HL requirement was also observed in lettuce for the harvesting and postharvesting operations $(28.3 \%)$, followed by the application of organic fertilizer (15.0\%), assembly of the irrigation system $(12.3 \%)$, hoeing $(10.4 \%)$, sidedressing $(8.4 \%)$ and others $(25.7 \%)$ (Table III). These results corroborate those found by Cecílio Filho (2005) and Rezende et al. (2005a, c) also for lettuce under protected cultivation.

Since the mechanized operations for the soil preparation in the intercropping system were identical to those carried out in the sole crop system (Table III), the amount of TrOL did not vary.

In the sole crop system, the depreciation cost ranged from US\$ 99.91 (lettuce) to US\$ 215.33 (cucumber with two rows) in $614.4 \mathrm{~m}^{2}$. The depreciation 
TABLE III

Technical coefficient and total cost of operations in dollars (US\$) for August 2007, for the production of Japanese cucumber 'Hokushin' with two and one row on the bed and lettuce in sole crop, under protected cultivation of $614.4 \mathrm{~m}^{2}$. Jaboticabal, SP, Brazil, 2007.

\begin{tabular}{|c|c|c|c|c|c|c|c|c|c|}
\hline \multirow{3}{*}{ Operation } & \multicolumn{3}{|c|}{ Two rows of cucumber } & \multicolumn{3}{|c|}{ One row of cucumber } & \multicolumn{3}{|c|}{ Lettuce } \\
\hline & $\mathrm{HL}^{1}$ & $\mathrm{TrOL}^{2}$ & $\mathrm{M}+\mathrm{I}^{3}$ & $\mathrm{HL}$ & TrOL & $\mathrm{M}+\mathrm{I}$ & HL & TrOL & $\mathrm{M}+\mathrm{I}$ \\
\hline & \multicolumn{9}{|c|}{ Technical Coefficients (hours in $614,4 \mathrm{~m}^{2}$ ) } \\
\hline Soil preparation & 1.00 & - & 1.00 & 1.00 & - & 1.00 & 1.00 & - & 1.00 \\
\hline Plowing $^{4}$ & - & 0.70 & 0.70 & - & 0.70 & 0.70 & - & 0.70 & 0.70 \\
\hline Bedding $^{4}$ & - & 0.85 & 0.85 & - & 0.85 & 0.85 & - & 0.85 & 0.85 \\
\hline Fertilization at planting time & 1.15 & - & & 1.15 & - & - & 1.15 & - & - \\
\hline Application of organic fertilizer & 11.00 & 0.30 & 0.30 & 11.00 & 0.30 & 0.30 & 11.00 & 0.30 & 0.30 \\
\hline Cultural practices & 32.00 & - & & 16.00 & - & - & 0.00 & - & - \\
\hline Assembly of irrigation system & 4.50 & - & & 2.25 & - & - & 9.00 & - & - \\
\hline Transplanting site identification & 0.77 & - & & 0.39 & - & - & 3.07 & - & - \\
\hline Transplanting & 1.15 & - & & 0.58 & - & - & 4.60 & - & - \\
\hline Hand hoeing & 10.50 & - & & 12.00 & - & - & 7.60 & - & - \\
\hline Sidedressing & 3.08 & - & & 1.54 & - & - & 6.14 & - & - \\
\hline Application of chemicals & 60.00 & - & 60.00 & 27.00 & - & 27.00 & 4.05 & - & 4.05 \\
\hline Irrigation & 10.38 & - & 41.50 & 10.38 & - & 41.50 & 5.00 & - & 20.00 \\
\hline Training/Suckering/Cropping & 75.00 & - & & 65.37 & - & - & - & - & - \\
\hline Harvesting and Postharvesting & 195.95 & - & $14.50^{5}$ & 87.10 & - & $9.57^{5}$ & 20.75 & - & $20.32^{5}$ \\
\hline Total Number of Hours & 406.48 & 1.85 & 118.85 & 235.76 & 1.85 & 80.92 & 73.36 & 1.85 & 47.22 \\
\hline A - Cost of operation & 599.59 & 3.13 & 42.58 & 347.76 & 3.13 & 40.05 & 108.21 & 3.13 & 37.64 \\
\hline Material & Amount & \multicolumn{2}{|c|}{ Value (US\$) } & Amount & \multicolumn{2}{|c|}{ Value (US\$) } & Amount & \multicolumn{2}{|c|}{ Value (US\$) } \\
\hline Formulation 12-06-12 (kg) & 10.10 & \multicolumn{2}{|c|}{4.62} & 10.10 & \multicolumn{2}{|c|}{4.62} & 10.10 & \multicolumn{2}{|c|}{4.62} \\
\hline Potassium Chloride (kg) & 10.37 & \multicolumn{2}{|c|}{5.65} & 5.19 & \multicolumn{2}{|c|}{2.82} & - & \multicolumn{2}{|c|}{-} \\
\hline Ammonium Nitrate (kg) & 23.04 & \multicolumn{2}{|c|}{11.60} & 11.52 & \multicolumn{2}{|c|}{5.80} & 18.43 & \multicolumn{2}{|c|}{9.28} \\
\hline Cattle manure (t) & 1.30 & \multicolumn{2}{|c|}{17.39} & 1.30 & \multicolumn{2}{|c|}{17.39} & 1.30 & \multicolumn{2}{|c|}{17.39} \\
\hline Herbicide (L) & 0.50 & \multicolumn{2}{|c|}{4.82} & 0.50 & \multicolumn{2}{|c|}{4.82} & 0.50 & \multicolumn{2}{|c|}{4.82} \\
\hline Transplant (unit) & 1,152 & \multicolumn{2}{|c|}{92.58} & 576.00 & \multicolumn{2}{|c|}{46.29} & 4,608 & \multicolumn{2}{|c|}{60.94} \\
\hline Chemicals & - & \multicolumn{2}{|c|}{130.76} & - & & & - & & 66 \\
\hline Plastic twine $(\mathrm{kg})$ & 7.20 & & & 3.60 & & & - & & - \\
\hline $\mathrm{B}-$ Cost of materials & & 290.53 & & & 171.76 & & & 111.72 & \\
\hline Effective operating cost $(\mathrm{A}+\mathrm{B})$ & & 935.83 & & & 562.70 & & & 260.70 & \\
\hline Depreciation Cost of item others & & 93.32 & & & 52.34 & & & 41.11 & \\
\hline Depreciation Cost of Greenhouse & & 122.01 & & & 122.01 & & & 58.80 & \\
\hline Total cost of operations (US\$ in $614.4 \mathrm{~m}^{2}$ ) & & $1,151.16$ & & & 737.05 & & & 360.62 & \\
\hline
\end{tabular}

${ }^{1} \mathrm{HL}$ - hand labor; ${ }^{2} \mathrm{TrOL}$ - tractor operator labor; ${ }^{3} \mathrm{M}+\mathrm{I}$ - machine and/or implement expenses; ${ }^{4}$ Fuel, maintenance, repairs, shelter and insurance went into the machine hourly cost; ${ }^{5} \mathrm{Hand}$ cart.

of the greenhouse alone accounts for 56.7\%, 70.0 and $58.9 \%$ of the total, for the cultivation of cucumber with two and one row on the bed and lettuce, respectively (Table III).

The TOC for cucumber cultivated in two and one row on the bed, intercropped with lettuce, amounted to US\$ $1,311.66$ and US\$ 916.07, respectively, in $614.4 \mathrm{~m}^{2}$
(Table IV). A higher TOC for the intercropping with two rows of cucumber is due to a larger number of plants, which resulted in higher costs of operations, and materials.

Operating costs accounted for $53.4 \%$, on the average, of the TOC, followed by costs of materials (26.6\%) and depreciation (21.4\%) (Table IV). 
TABLE IV

Technical coefficient and total cost of operations in dollars (US\$) for August 2007, for the production of Japanese cucumber 'Hokushin' cultivated in two $(2 \mathrm{R})$ and one row $(1 \mathrm{R})$ on the bed intercropped with lettuce 'Verônica' under greenhouse of $614.4 \mathrm{~m}^{2}$. Jaboticabal, SP, Brazil, 2007.

\begin{tabular}{|c|c|c|c|c|c|c|}
\hline \multirow{3}{*}{ Operations } & \multicolumn{3}{|c|}{ Cucumber $2 \mathrm{R}$ with Lettuce } & \multicolumn{3}{|c|}{ Cucumber $1 \mathrm{R}$ with Lettuce } \\
\hline & $\mathrm{HL}^{1}$ & $\mathrm{TrOL}^{2}$ & $\mathrm{M}+\mathrm{I}^{3}$ & HL & TrOL & $\mathrm{M}+\mathrm{I}$ \\
\hline & \multicolumn{6}{|c|}{ Technical Coefficients (hours in $614.4 \mathrm{~m}^{2}$ ) } \\
\hline Soil preparation & 1.00 & - & 1.00 & 1.00 & - & 1.00 \\
\hline Plowing $^{4}$ & - & 0.70 & 0.70 & - & 0.70 & 0.70 \\
\hline Bedding $^{4}$ & - & 0.85 & 0.85 & - & 0.85 & 0.85 \\
\hline Fertilization at planting time & 1.15 & - & - & 1.15 & - & - \\
\hline Application of organic fertilizer & 11.00 & 0.30 & 0.30 & 11.00 & 0.30 & 0.30 \\
\hline Cultural practices & 32.00 & - & - & 16.00 & - & - \\
\hline Assembly of irrigation system & 9.00 & - & - & 9.00 & - & - \\
\hline Transplanting site identification & 3.84 & - & - & 3.46 & - & - \\
\hline Transplanting & 5.75 & - & - & 5.18 & - & - \\
\hline Hand hoeing & 10.50 & - & - & 12.00 & - & - \\
\hline Sidedressing & 9.22 & - & - & 7.68 & - & - \\
\hline Application of chemicals & 60.00 & - & 60.00 & 27.00 & - & 27.00 \\
\hline Irrigation & 10.38 & - & 41.50 & 10.38 & - & 41.50 \\
\hline Training/Suckering/Cropping & 75.00 & - & - & 65.37 & - & - \\
\hline Harvesting and Postharvesting & 216.70 & - & $34.82^{5}$ & 107.85 & - & $29.89^{5}$ \\
\hline Total Number of Hours & 445.54 & 1.85 & 139.17 & 277.07 & 1.85 & 101.24 \\
\hline A - Cost of operation & 657.21 & 3.13 & 44.02 & 408.70 & 3.13 & 41.49 \\
\hline Material & Amount & \multicolumn{2}{|c|}{ Value (US\$) } & Amount & \multicolumn{2}{|c|}{ Value (US\$) } \\
\hline Formulation 12-06-12 (kg) & 10.10 & \multicolumn{2}{|c|}{4.62} & 10.10 & \multicolumn{2}{|c|}{4.62} \\
\hline Potassium Chloride (kg) & 10.37 & \multicolumn{2}{|c|}{5.65} & 5.19 & \multicolumn{2}{|c|}{2.82} \\
\hline Ammonium Nitrate $(\mathrm{kg})$ & 41.47 & \multicolumn{2}{|c|}{20.89} & 26.34 & \multicolumn{2}{|c|}{13.27} \\
\hline Cattle manure $(\mathrm{t})$ & 1.30 & \multicolumn{2}{|c|}{17.39} & 1.30 & \multicolumn{2}{|c|}{17.39} \\
\hline Herbicide (L) & 0.50 & \multicolumn{2}{|c|}{4.82} & 0.50 & \multicolumn{2}{|c|}{4.82} \\
\hline Cucumber transplant (unit) & $1,152.00$ & \multicolumn{2}{|c|}{92.58} & 576.00 & \multicolumn{2}{|c|}{46.29} \\
\hline Lettuce transplant (unit) & $4,608.00$ & \multicolumn{2}{|c|}{60.94} & $4,608.00$ & \multicolumn{2}{|c|}{60.94} \\
\hline Chemicals & - & \multicolumn{2}{|c|}{130.76} & - & \multicolumn{2}{|c|}{78.46} \\
\hline Plastic twine $(\mathrm{kg})$ & 7.20 & \multicolumn{2}{|c|}{23.11} & 3.60 & \multicolumn{2}{|c|}{11.56} \\
\hline $\mathrm{B}$ - Cost of materials & \multicolumn{3}{|c|}{360.76} & \multicolumn{3}{|c|}{219.42} \\
\hline Effective operating cost $(\mathrm{A}+\mathrm{B})$ & \multicolumn{3}{|c|}{$1,065.12$} & \multicolumn{3}{|c|}{647.54} \\
\hline Depreciation Cost of item others & & 124.53 & & & 82.98 & \\
\hline Depreciation Cost of Greenhouse & & 122.01 & & & 122.01 & \\
\hline Total cost of operations (US\$ in $614.4 \mathrm{~m}^{2}$ ) & & $1,311.66$ & & & 852.53 & \\
\hline
\end{tabular}

${ }^{1} \mathrm{HL}$ - hand labor; ${ }^{2} \mathrm{TrOL}$ - tractor operator labor; ${ }^{3} \mathrm{M}+\mathrm{I}$ - machine and/or implement expenses; ${ }^{4}$ Fuel, maintenance, repairs, shelter and insurance went into the machine hourly cost; ${ }^{5}$ Hand cart. 
The estimated TOC for intercropping cultivation showed an increase in labor in comparison to that required for sole crop with the same plant population. This higher labor requirement for intercropping is due to operations that are not shared by the two crops, such as cultural practices, transplanting site identification, transplanting, top-dressing, training, suckering, cropping, harvesting and postharvesting. This was also observed by Cecílio Filho (2005) and Rezende et al. (2005a) when crisphead lettuce was intercropped with tomato under protected cultivation.

Though HL is the largest component of the TOC for intercropping, a lower HL requirement was observed; $445.54 \mathrm{~h}$ (Table IV) for intercropping with cucumber cultivated in two rows on the bed, in comparison to that for the sum of HL requirements in the sole crop system, which was $479.84 \mathrm{~h}$ (Table III). The 34.30hour reduction in the amount of HL is attributed to operations shared by both crops, that is, operations referring to soil preparation, plowing, bedding, application of organic fertilizer, assembly of the irrigation system, hoeing, application of chemicals, and irrigation, which were carried out for one crop and used by the other crop of intercropping. This also occurred in the intercropping with one row of cucumber on the bed, in which the reduction in the HL requirement was of 32.05 hours. The fuel for the machine, irrigation system, machinery and implements were also optimized, thus lessening the weight of depreciation in the TOC for the crops in the intercropping system.

By intercropping tomato with crisphead lettuce under protected cultivation, Cecílio Filho (2005) and Rezende et al. (2005a) saved 26.22 and 15.40 hours of $\mathrm{HL}$, respectively. In field condition, the HL saving, in comparison to sole crop, can also be significant; about 480 hours for the intercropping of pepper and lettuce (Rezende et al. 2005d), 728 hours for the intercropping of lettuce and arugula (Costa 2006), and 296 hours for the intercropping of crisphead lettuce and radish (Rezende et al. 2005b).

The optimization of labor by the intercropping system, according to Puiatti et al. (2000), is one of the most significant advantages of this cultivation system in comparison to the sole crop, thus allowing a better profitability of the activity. Moreover, it can contribute to the reduction in the production cost for the secondary or associated crop (Rezende et al. 2005c). These authors observed a $39.5 \%$ reduction in the TOC for lettuce when it was intercropped with tomato in comparison to its sole crop. From those authors, transplant and chemicals were the most expensive, accounting for 45.7 and $36.0 \%$, respectively, on the average (Table IV). Since the cost of transplant was a major factor that contributed to the TOC in sole crop and intercropping, the grower must choose a company carefully, purchasing transplant from a company which that has the know-how and complying with the standards and special care involved in their production, such as the use of certified seed and the strict control of disease vectors and pathogens. Using good-quality transplant is a key to success in cultivation.

Similarly to what was observed in the sole crop, the depreciation cost of the greenhouse in intercropping accounted for $54.5 \%$, on the average, of the total cost of depreciation, and $11.8 \%$ of the TOC (Table IV).

\section{ANALYSIS OF INTERCROPPING PROFITABILITY}

Lettuce yields for the crops established at 20 and 30 DAT of cucumber, when intercropped with two rows of cucumber on the bed, have not been included in the analysis because reason of physiological disorders (morphological alterations), which caused etiolation, mass reduction and production of latex, thus detracting from the characteristics of the product and affecting its marketing. This shows how cucumber plants affected lettuce (darkness) as lettuce was transplanted at later dates. This type of effect was also observed for lettuce intercropped with one row of cucumber on the bed, though less strong. Despite the fact that cucumber had a lower population density, the lettuce harvested from intercropping established at 10;20 and 30 DAT of cucumber was assigned as lower class for marketing, in comparison to the lettuce harvested from intercropping established at 0 DAT of cucumber and in sole crop (Table V).

A significant reduction in yield was observed for cucumber cultivated in one row in comparison to cucumber cultivated in two rows (Table V). The presence of lettuce did not affect the cucumber yield in comparison to that from sole crop. 
TABLE V

Crop yield ( $\mathrm{kg}$ in $614.4 \mathrm{~m}^{2}$ ) of lettuce 'Verônica' and Japanese cucumber 'Hokushin' cultivated in two and one row on the bed in intercropping and sole crop. Jaboticabal, SP, Brazil, 2007.

\begin{tabular}{|c|c|c|c|c|c|c|}
\hline \multirow{3}{*}{ Cultivation System } & \multicolumn{3}{|c|}{ Cucumber } & \multicolumn{3}{|c|}{ Lettuce } \\
\hline & $\mathrm{PC} 15+20^{2}$ & $\mathrm{PC} 25^{3}$ & $\mathrm{PFT}^{4}$ & Special $^{5}$ & Extra $^{5}$ & First $^{5}$ \\
\hline & \multicolumn{6}{|c|}{ Two rows of cucumber } \\
\hline Intercropping at $0 \mathrm{DAT}^{1}$ & 2,985 & 165.89 & 889.34 & 824.83 & - & - \\
\hline Intercropping at $10 \mathrm{DAT}$ & 2,924 & 468.86 & 928.51 & - & - & 479.23 \\
\hline Intercropping at $20 \mathrm{DAT}$ & 3,021 & 150.91 & 617.47 & - & - & - \\
\hline Intercropping at $30 \mathrm{DAT}$ & 3,298 & 346.75 & 928.51 & - & - & - \\
\hline Sole crop of cucumber & 2,739 & 387.07 & 816.77 & - & - & - \\
\hline Sole crop of lettuce at 0 DAT & - & - & - & $1,087.49$ & - & - \\
\hline Sole crop of lettuce at $10 \mathrm{DAT}$ & - & - & - & 815.62 & - & - \\
\hline Sole crop of lettuce at 20 DAT & - & - & - & 755.71 & - & - \\
\hline \multirow[t]{2}{*}{ Sole crop of lettuce at 30 DAT } & - & - & - & 903.17 & - & - \\
\hline & \multicolumn{6}{|c|}{ One row of cucumber } \\
\hline Intercropping at $0 \mathrm{DAT}$ & 1,744 & 197.57 & 566.21 & 1,046 & - & \\
\hline Intercropping at $10 \mathrm{DAT}$ & 1,714 & 184.32 & 486.14 & - & - & 658.94 \\
\hline Intercropping at $20 \mathrm{DAT}$ & 1,499 & 203.33 & 423.36 & - & - & 465.41 \\
\hline Intercropping at $30 \mathrm{DAT}$ & 1,583 & 134.78 & 398.59 & - & - & 465.41 \\
\hline Sole crop of cucumber & 1,697 & 89.28 & 571.39 & - & - & - \\
\hline Sole crop of lettuce at 0 DAT & - & - & - & - & 1,290 & - \\
\hline Sole crop of lettuce at 10 DAT & - & - & - & - & 1,217 & - \\
\hline Sole crop of lettuce at 20 DAT & - & - & - & 1,147 & - & - \\
\hline Sole crop of lettuce at 30 DAT & - & - & - & 1,074 & - & - \\
\hline
\end{tabular}

The GR from intercropping was always higher than those from the sole crop even when the yield of lettuce was not included (Table VI). The OP from intercropping established with the transplant of lettuce at 0,10 and 30 DAT of cucumber, with two rows on the bed, behaved likewise, whereas those from intercropping with one row on the bed were higher only when the intercropping was established at 0 DAT (Table VI). The highest OP was obtained from intercropping with two rows of cucumber (US\$ 342.68 in $614.4 \mathrm{~m}^{2}$ ) and one row on the bed (US\$ 249.21 in $614.4 \mathrm{~m}^{2}$ ) established with the transplant of lettuce and cucumber on the same date, surpassing those from cucumber sole crop in $56.0 \%$ and $207.1 \%$, respectively (Table VI). Higher profitability of these intercropping was the result of higher yield furnished by cucumber and lettuce in comparison to the others.

The opposite was obtained from intercropping established at 20 DAT of cucumber with two rows, and at 10, 20 and 30 DAT of cucumber with one row on the bed (Table VI). In these intercroppings, a reduction in cucumber yield, together with that in lettuce, caused by the competition of cucumber plants against lettuce, accounted for the worst economic performance of these dates of intercropping establishment. The low yield reflected directly on the grading of the lettuce and consequently on the price. However, for intercropping established at 10,20 and 30 DAT of cucumber with one row, the price per kilogram of lettuce was, on the average, $33.9 \%$ lower than that at 0 DAT (US\$ $0.28 \mathrm{~kg}^{-1}$ ). 
TABLE VI

Gross revenue (GR), Total cost of operations (TCO), Operating profit (OP) and Land Equivalent Ratio (LER) of lettuce 'Verônica' and Japanese cucumber 'Hokushin' cultivated in two and one row on the bed in intercropping and sole crop. Jaboticabal, SP, Brazil, 2007.

\begin{tabular}{|c|c|c|c|c|}
\hline \multirow{3}{*}{ Cultivation System } & $\mathrm{GR}^{2}$ & $\mathrm{TCO}$ & $\mathrm{OP}$ & LER \\
\hline & \multicolumn{4}{|c|}{ Two rows of cucumber } \\
\hline & \multicolumn{3}{|c|}{ US\$ in $614.4 \mathrm{~m}^{2}$} & - \\
\hline Intercropping at $0 \mathrm{DAT}^{1}$ & $1,654.34$ & $1,311.66$ & 342.68 & 1.82 \\
\hline Intercropping at $10 \mathrm{DAT}$ & $1,580.46$ & $1,311.66$ & 268.80 & 1.68 \\
\hline Intercropping at $20 \mathrm{DAT}$ & $1,376.85$ & $1,311.66$ & 65.19 & 1.30 \\
\hline Intercropping at $30 \mathrm{DAT}$ & $1,605.31$ & $1,311.66$ & 293.65 & 1.31 \\
\hline Sole crop of cucumber & $1,370.89$ & $1,151.16$ & 219.73 & - \\
\hline Sole crop of lettuce at 0 DAT & 309.76 & 360.62 & $(50.85)$ & - \\
\hline Sole crop of lettuce at 10 DAT & 232.32 & 360.62 & $(128.30)$ & - \\
\hline Sole crop of lettuce at 20 DAT & 215.26 & 360.62 & $(145.36)$ & - \\
\hline \multirow[t]{2}{*}{ Sole crop of lettuce at $30 \mathrm{DAT}$} & 243.48 & 360.62 & (117.14) & - \\
\hline & \multicolumn{4}{|c|}{ One row of cucumber } \\
\hline Intercropping at 0 DAT & $1,165.28$ & 916.07 & 249.21 & 1.80 \\
\hline Intercropping at $10 \mathrm{DAT}$ & 959.99 & 916.07 & 43.92 & 1.41 \\
\hline Intercropping at $20 \mathrm{DAT}$ & 830.62 & 916.07 & $(85.46)$ & 1.38 \\
\hline Intercropping at $30 \mathrm{DAT}$ & 835.01 & 916.07 & $(81.06)$ & 1.26 \\
\hline Sole crop of cucumber & 818.19 & 737.05 & 81.14 & - \\
\hline Sole crop of lettuce at 0 DAT & 498.77 & 360.62 & 138.15 & - \\
\hline Sole crop of lettuce at 10 DAT & 470.27 & 360.62 & 109.65 & - \\
\hline Sole crop of lettuce at 20 DAT & 326.83 & 360.62 & $(33.79)$ & - \\
\hline Sole crop of lettuce at 30 DAT & 289.44 & 360.62 & $(71.17)$ & - \\
\hline
\end{tabular}

On the other hand, for intercropping established at 20 DAT of cucumber with two rows, a major reduction in the quality of the lettuce caused its marketing disqualification. In those cases, the agronomic superiority revealed by the LER, which ranged from 1.26 and 1.41 , was not translated into economic advantage (Table VI). Thus, the need to carry out an economic analysis of intercropping as proposed by Zanatta et al. (1993) is confirmed, so that the results obtained from different cropping systems can be better interpreted. The use of LER alone as a comparison index for different situations of intercropping may lead to error due to the fact that this index is based on a ratio, and high values of LER may be obtained not only as a result from high intercropping yields, but also as a result from low sole crop yields
(Mead and Willey 1980). For Beltrão et al. (1984), LER gives only the physical measure of the system without considering the value of each component of the intercropped system.

In general, although the TOC for the intercropping system was higher than that for sole crop, a significant increase in the number of the product (lettuce + cucumber) per area in the intercropping reflected positively on the gross revenue, thus resulting in higher net revenue (Table VI). This is in agreement with the paper by Oliveira et al. (2004), Pôrto et al. (2004), Rezende et al. (2005a, b, d), Cecílio Filho (2005) and Costa (2006) who declare that they obtain better economic returns in intercropping than in sole crop, especially because of the higher gross revenue that the system produces. 
According to Cecílio Filho (2005), the benefit obtained from the association of crops goes beyond that based on the difference between operating costs of sole crop and intercropping. Water, fertilizers and other materials are better used, as cited by Horwith (1985), which can account for a possible greater environmental impact when poorly managed. The optimization of the area of small agricultural properties, as well as of the greenhouse, which is an expensive structure, either for purchasing and/or building, or its maintenance (replacement of the polyethylene film used for covering the ceiling), is very important.

In all the intercropped systems analyzed, the cucumber crop accounted for a large part in the composition of gross revenue and operating profit of the intercropping by virtue of higher yield and better price of the fruits in comparison to lettuce.

Although the prices for Japanese cucumber and lettuce were low in the wholesale sector from August to November, treatments with market productivity of lettuce indicate that the vegetables intercropping was economically viable with the establishment of lettuce at 0 and 10 DAT of cucumber cultivated in two rows and at 0 DAT of cucumber cultivated in one row on the bed. Nevertheless, it must be pointed out that the vegetables vary in their market characteristics, price and production cost year-round. According to Pôrto et al. (2004), though the yields of the crops depend on the time of the year they are cultivated, the study of the effect of seasonality on prices throughout the year for the vegetables in question allows us to obtain information on how the economic profitability of a given crop may vary. Therefore, depending on the price of the vegetables involved in the intercropping, this combination of crops economically viable, at a given time of the year, may not have the same profit or even be unsatisfactory in comparison to sole crop.

Labor was the component with the largest part in the TOC for the crops in sole crop and intercropping. Higher GR and OP were observed for intercropping established with the transplant of lettuce and cucumber on the same date, regardless of the plant population density. Intercropping established with the transplant of both crops on the same date, and with one row of cucumber on the bed, gives the highest operating profit in comparison to the cucumber sole crop. By considering the operating profit and the land equivalent ratio, the recommended intercropping is that with the transplant of lettuce up to 10 days after the transplanting of cucumber, with two rows, and at 0 DAT of cucumber planted in one row on the bed.

\section{RESUMO}

A análise econômica complementa a avaliação da eficiência dos cultivos consorciados, considerando além da produção física das culturas, o preço dos produtos segundo sua classificação qualitativa e época do ano. Avaliou-se economicamente consórcios de alface crespa e pepino, em duas populações de plantas, no inverno-primavera, em casa de vegetação, em Jaboticabal, SP, Brasil. Foram calculados o custo operacional total (COT), a receita bruta (RB) e o lucro operacional (LO) das culturas do pepino e alface em monocultura e em consórcio. A mão-de-obra foi a componente com maior participação no COT das culturas em consórcio e monocultura. Maiores RB e LO foram observadas nos cultivos consorciados estabelecidos com o transplante da alface e do pepino no mesmo dia, independente da densidade populacional. Considerando-se o lucro operacional e o índice de uso eficiente da área, recomenda-se o cultivo consorciado com transplante da alface até 10 dias após o transplante (DAT) do pepino, com duas linhas, e ao 0 DAT do pepino cultivado com uma linha no canteiro.

Palavras-chave: Lactuca sativa, Cucumis sativus, viabilidade econômica, eficiência agronômica.

\section{REFERENCES}

Beltrão NEM, Nobrega LB, Azevedo DMP AND VIEIRA DJ. 1984. Comparação entre indicadores agroeconômicos de avaliação de agroecossistemas consorciados e solteiros envolvendo algodão "Upland" e feijão "Caupi". Campina Grande, 21 p. (Boletim de Pesquisa, 15).

CAÑIZARes KAL. 1998. A cultura do pepino. In: Goto R AND TIVELli SW. Produção de hortaliças em ambiente protegido: condições subtropicais. São Paulo: Unesp, p. 221-223.

CEAGESP - COMPANHIA DE ENTREPOSTOS E ARMAZÉnS DE SÃo PAUlo. 2006. Preço médio mensal da alface crespa no ano de 2006. Departamento de Economia, São Paulo.

Cecílio Filho AB. 2005. Cultivo consorciado de hortaliças: desenvolvimento de uma linha de pesquisa. Univer- 
sidade Estadual Paulista, Faculdade de Ciências Agrárias e Veterinárias. (Tese de Livre-docência), 135 p.

Costa CC. 2006. Consórcio de alface e rúcula: aspectos produtivos e econômicos. Universidade Estadual Paulista, Faculdade de Ciências Agrárias e Veterinárias. (Tese de Doutorado em Produção Vegetal), 83 p.

HoRwith B. 1985. A role for intercropping in modern agriculture. BioScienc 35: 286-291.

HORTIBRASIL. 2006. Alface e Pepino: classe e defeitos variáveis. Disponível em: http://www.hortibrasil.org.br.

Matsunaga M, Bemelmans PF, Toledo PEN, Dulley RD, OKawa H ANd Pedroso IA. 1976. Metodologia de custo de produção utilizada pelo IEA. Agricultura em São Paulo 23: 123-139.

MEAD R AND Willey RW. 1980. The concept of a 'land equivalent ratio' and advantages in yields from intercropping. Expl agric 16: 217-228.

Oliveira EQ, Bezerra Neto F, Negreiros MZ AND BArRos JUnior AP. 2004. Desempenho agroeconômico do bicultivo de alface em sistema solteiro e consorciado com cenoura. Horti Bras 22: 712-717.

PôRTo DRQ, Rezende BLA, Cecílio Filho AB, URBINATI E AND MARTINS MIEG. 2004. Viabilidade econômica do consórcio alface e rabanete, em função da sazonalidade de preços. Horti Bras 22. (CD-ROM).

Puiatti M, FÁvero C, Finger FL And Gomes JM. 2000. Crescimento e produtividade de inhame e de milho doce em cultivo associado. Horti Bras 18: 24-30.

Rezende BLA, CANATo GHD AND Cecílio Filho AB. 2005a. Influência das épocas de cultivo e do estabelecimento do consórcio na produção de tomate. Cienc Agrotecnol 29: 77-83.

Rezende Bla, Cecílio Filho AB, Catelan F and MARTINS MIEG. 2005b. Análise econômica de consórcios de alface americana $\times$ rabanete: um estudo de caso. Horti Bras 23: 853-858.
Rezende Bla, Cecílio Filho AB, Martins MieG AND Costa CC. 2005c. Custo de produção e rentabilidade da alface crespa, em ambiente protegido, em cultivo solteiro e consorciado com tomateiro. Informações Econômicas 35: 42-50.

Rezende Bla, Cecílio Filho AB, Martins MieG, Costa CC AND Feltrim AL. 2005d. Viabilidade econômica das culturas de pimentão, repolho, alface, rabanete e rúcula em cultivo consorciado, na primavera-verão, Jaboticabal, estado de São Paulo. Informações Econômicas 35: 22-37.

SAntos APR AND JUnQUeIRA AMR. 2004. Análise econômico-financeira da produção de tomate e pimentão no Distrito Federal: um estudo de caso. Horti Bras 22. (CDROM).

Trani PE, Passos FA and Azevedo Filho JA. 1997a. Alface, almeirão, chicória, escarola, rúcula e agrião d'agua. In: RAIJ B VAN, CANTARELla H, QUAGgio JA AND FURLANI AMC. Recomendações de adubação e calagem para o estado de São Paulo. Campinas: IAC, p. 168-169.

Trani Pe, Passos FA, Melo amt, Scivittaro WB AND NAGAi H. 1997b. Abobrinha ou abóbora de moita; abóbora rasteira, moranga e híbridos; bucha e pepino. In: Raij BV, CANTARElla H, QuAgGio JÁ AND FURlaNI AMC. Recomendações de adubação e calagem para o Estado de São Paulo. Campinas: IAC, 165 p.

Zanatta JC, Schiocchet MA AND NAdAL R. 1993. Mandioca consorciada com milho, feijão ou arroz de sequeira no Oeste Catarinense. Florianópolis: Empresa de Pesquisa Agropecuária e Difusão de Tecnologia de Santa Catarina, 36 p. (Boletim Técnico). 